\title{
PENGERTIAN, UNSUR, PRINSIP, DAN RUANG LINGKUP PERENCANAAN PENDIDIKAN
}

\author{
Fatkhul Mubin \\ fatkhulmubin90@gmail.com
}

\begin{abstract}
Abstrak
Tulisan ini bertujuan untuk menguraikan tentang pengertian, unsur, prinsip, dan ruang lingkup perencanaan pendidikan. Pendidikan merupakan komponen terpenting dalam kehidupan sehari-hari. Pendidikan mempunyai peranan dan fungsi yang cukup penting bagi kehidupan manusia, baik pendidikan dalam aspek kognitif, afektif (sikap), maupun psikomotorik. Oleh karena itu, sudah menjadi suatu keharusan bagi manusia untuk dapat merasakan proses tersebut. Ia diakui sebagai kekuatan yang dapat mendorong manusia mencapai kemajuan peradaban. Selain itu pendidikan memberikan bekal kepada manusia untuk menyongsong hari esok yang lebih cerah dan lebih manusiawi.
\end{abstract}

\section{Kata Kunci: Pengertian, Unsur, Ruang Lingkup, Perencanaan Pendidikan}

\section{PENDAHULUAN}

Pendidikan merupakan komponen terpenting dalam kehidupan sehari-hari. Pendidikan mempunyai peranan dan fungsi yang cukup penting bagi kehidupan manusia, baik pendidikan dalam aspek kognitif, afektif (sikap), maupun psikomotorik. Oleh karena itu, sudah menjadi suatu keharusan bagi manusia untuk dapat merasakan proses tersebut. Ia diakui sebagai kekuatan yang dapat mendorong manusia mencapai kemajuan peradaban. Selain itu pendidikan memberikan bekal kepada manusia untuk menyongsong hari esok yang lebih cerah dan lebih manusiawi.

Sedangkan, dalam menjalankan sebuah aktivitas sehari-hari, manusia tidak bisa lepas dengan adanya sebuah perencanaan. Dengan adanya perencanaan yang bagus, maka aktivitas sehari-hari dapat berjalan dengan baik sesuai dengan tujuan yang diharapkan. Karena perencanaan merupakan suatu rangkaian proses menyiapkan dan menentukan seperangkat keputusan mengenai apa yang diharapkan dan apa yang akan dilakukan. Rangkaian proses kegiatan itu dilaksanakan agar harapan tersebut dapat terwujud menjadi suatu kenyataan

Perencanaan pendidikan merupakan kunci efektivitas suatu kegiatan untuk mencapai tujuan pendidikan yang diharapkan dan direncanakan. Oleh karena itu, dalam pembahasan makalah ini, kami akan membahas tentang gabaimana perencanaan pendidikan itu sehingga perencanaan yang direncanakan dapat maksimal dan tujuan utamanya dapat tercapai.

\section{PEMBAHASAN}

\section{A. Pengertian Perencanaan Pendidikan}

1. Pengertian Perencanaan

Perencanaan adalah proses penentuan tujuan atau sasaran yang hendak dicapai dan menetapkan jalan dan sumber yang diperlukan untuk mencapai tujuan itu seefisien dan seefektif mungkin. ${ }^{1}$ Perencanaan sering disebut jembatan yang menghubungkan kesenjangan atau jurang antara keadaan masa

1 Kahar Utsman \& Nadhirin, Perencanaan Pendidikan, Kudus: STAIN Kudus, 2008, hlm. 1 
kini dan keadaan yang diharapkan terjadi pada masa yang akan datang. Dengan demikian, perencanaan yang baik memperhatikan sifat-sifat kondisi yang akan datang, di mana keputusan efektif dilaksanakan. ${ }^{2}$

Perencanan tidaklah dikembangkan berdasarkan teori tetapi sebaliknya teori perencanaan berkembang sebagai kelanjutan dari pengalaman mengenai usaha-usaha manusia untuk mengatasi keadaan lingkungan hidupnya. ${ }^{3}$ Perencanaan juga merupakan suatu rangkaian kegiatan berfikir yang bersinambungan dan rasional untuk memecahkan suatu permasalahan sacara sistematik, efektif dan efisien. ${ }^{4}$

Dari definisi diatas dapat disimpulkan bahwa perencanaan adalah suatu cara yang memuaskan untuk membuat organisasi tetap berdiri tegak dan maju sebagai satu sistem. ${ }^{5}$ Sedangkan, definisi perencanaan pendidikan dalam arti yang seluas-luasnya adalah penggunaan analisis yang bersifat rasional dan sistematik terhadap proses pengembangan pendidikan yang bertujuan untuk menjadikan pendidikan menjadi lebih efektif dan efisien dalam menanggapai kebutuan dan tujuan murid-murid dan masyarakat. ${ }^{6}$

2 Saihu, S. (2019). RINTISAN PERADABAN PROFETIK UMAT MANUSIA MELALUI PERISTIWA TURUNNYA ADAM AS KE-DUNIA. Mumtaz: Jurnal Studi Al-Quran dan Keislaman, 3(2), 268-279, Saihu, S. (2019). Pendidikan Pluralisme Agama: Kajian tentang Integrasi Budaya dan Agama dalam Menyelesaikan Konflik Sosial Kontemporer. Jurnal Indo-Islamika, 9(1), 67-90, Saihu, S. (2019). IMPLEMENTASI MANAJEMEN BALANCED SCORECARD DI PONDOK PESANTREN JAM'IYYAH ISLAMIYYAH TANGERANG SELATAN. Mumtaz: Jurnal Studi Al-Quran dan Keislaman, 3(1), 1-22, Saihu, S. (2019). KOMUNIKASI PENDIDIK TERHADAP ANAK BERKEBUTUHAN KHUSUS DI SEKOLAH KHUSUS ASY-SYIFA LARANGAN. Andragogi: Jurnal Pendidikan Islam dan Manajemen Pendidikan Islam, 1(3), 418-440, Saihu, S., \& Marsiti, M. (2019). PENDIDIKAN KARAKTER DALAM UPAYA MENANGKAL RADIKALISME DI SMA NEGERI 3 KOTA DEPOK, JAWA BARAT. Andragogi: Jurnal Pendidikan Islam dan Manajemen Pendidikan Islam, 1(1), 23-54, Saihu, S. (2019). KONSEP MANUSIA DAN IMPLEMENTASINYA DALAM PERUMUSAN TUJUAN PENDIDIKAN ISLAM MENURUT MURTADHA MUTHAHHARI. Andragogi: Jurnal Pendidikan Islam dan Manajemen Pendidikan Islam, 1(2), 197-217, Saihu, S., \& Rohman, B. (2019). PEMBENTUKAN KARAKTER MELALUI MODEL PENDIDIKAN TRANSFROMATIFE LEARNING PADA SANTRI DI PONDOK PESANTREN NURUL IKHLAS BALI. Edukasi Islami: Jurnal Pendidikan Islam, 8(02), 435-452. Saihu, S., \& Taufik, T. (2019). PERLINDUNGAN HUKUM BAGI GURU. Al Amin: Jurnal Kajian Ilmu dan Budaya Islam, 2(2), 105116. Saihu, S. (2020). KONSEP PEMBAHARUAN PENDIDIKAN ISLAM MENURUT FAZLURRAHMAN. Andragogi: Jurnal Pendidikan Islam dan Manajemen Pendidikan Islam, 2(1), 82-95, Saihu, S. (2020). ETIKA MENUNTUT ILMU MENURUT KITAB TA'LIM MUTA'ALIM. Al Amin: Jurnal Kajian Ilmu dan Budaya Islam, 3(1), 99-112, Saihu, Aziz, A., Mubin, F., \& Sarnoto, A. Z. (2020). Design of islamic education based on local wisdom (An analysis of social learning theories in forming character through ngejot tradition in bali). International Journal of Advanced Science and Technology, 29(6), 1278-1293, Ronaldo, R., Zulfikar, A., Saihu, Ismail, \& Wekke, I. S. (2020). International relations of the asia pacific in the age of trump. Journal of Environmental Treatment Techniques, 8(1), 244-246.

3 Saraswati, Kearifan Budaya Lokal Dalam Persfektif Teori Perencanaan, Jurnal PWK Unisba, hlm. 4

4 Ibid., hlm.7

5 Made Pidarta, Perencanaan Pendidikan Partisipatoris Dengan Pendekatan Sistem, Jakarta: Rineka Cipta, 1990, hlm. 3

6 Saihu, M. M., \& Aziz, A. (2020). Implementasi Metode Pendidikan Pluralisme Dalam Mata Pelajaran Pendidikan Agama Islam. Belajea; Jurnal Pendidikan Islam, 5(1), 131-150, Saihu, M. (2019). Urgensi 'Urf dalam Tradisi Male dan Relevansinya dalam Dakwah Islam di Jembrana-Bali. Jurnal Bimas Islam, 12(1), 173-201, Saihu, S. (2020). The Effect of Using Talking Stick Learning Model on Student Learning Outcomes in Islamic Primary School of Jamiatul Khair, Ciledug Tangerang. Tarbawi: Jurnal Keilmuan Manajemen Pendidikan, 6(01), 61-68, Saihu, S. (2020). Pendidikan sosial yang terkandung 


\section{Pengertian Pendidikan}

Prof Langeveld seorang ahli pedagogic dari Negeri Belanda mengemukakan batasan pendidikan, bahwa pendidikan ialah suatu bimbingan yang diberikan oleh orang dewasa kepada anak yang belum dewasa untuk mencapai tujuan yaitu kedewasaan. ${ }^{7}$ Dengan pendidikan, manusia akan memiliki kemampuan dan kepribadian yang berkembang, membimbing generasi muda untuk mencapai suatu generasi yang lebih baik.

Pendidikan memperhatikan kesatuan aspek jasmani dan rohani, aspek diri (individualitas) dan aspek sosial, aspek kognitif, afektif, dan psikomotorik, serta keterhubungan manusia dengan dirinya (konsentris), dengan lingkungan sosial dan alamnya (horozontal), dan dengan Tuhannya (vertikal). ${ }^{8}$

3. Pengertian Perencanaan Pendidikan

Adapun definisi Perencanaan Pendidikan menurut para ahli atau para pakar manajemen adalah antara lain :

a. Menurut, Prof. Dr. Yusuf Enoch

Perencanaan Pendidikan, merupakan suatu proses yang yang mempersiapkan seperangkat alternative keputusan bagi kegiatan masa depan yang diarahkan kepadanpencapaian tujuan dengan usaha yang optimal dan mempertimbangkan kenyataan-kenyataan yang ada di bidang ekonomi, sosial budaya serta menyeluruh suatu Negara.

b. Beeby, C.E.

Perencanaan Pendidikan merupakan suatu usaha melihat ke masa depan ke masa depan dalam hal menentukan kebijaksanaan prioritas, dan biaya pendidikan yang mempertimbangkan kenyataan kegiatan yang ada dalam bidang ekonomi, social, dan politik untuk mengembangkan potensi system pendidikan nasioanal memenuhi kebutuhan bangsa dan anak didik yang dilayani oleh system tersebut.

c. Menurut Guruge (1972)

Perencanaan Pendidikan merupakan proses mempersiapkan kegiatan di masa depan dalam bidang pembangunan pendidikan.

d. Menurut Albert Waterson (Don Adam 1975)

Perencanaan Pendidikan adala investasi pendidikan yang dapat dijalankan oleh kegiatan-kegiatan pembangunan lain yang di dasarkan atas pertimbangan ekonomi dan biaya serta keuntungan sosial.

e. Menurut Coombs (1982)

Perencanaan pendidikan suatu penerapan yang rasional dianalisis sistematis proses perkembangan pendidikan dengan tujuan agar pendidikan itu lebih

dalam Surat At-Taubah Ayat 71-72. Edukasi Islami: Jurnal Pendidikan Islam, 9(01), 127-148, Aziz, A., \& Saihu, S. (2019). Interpretasi Humanistik Kebahasaan: Upaya Kontekstualisasi Kaidah Bahasa Arab. Arabiyatuna: Jurnal Bahasa Arab, 3(2), 299-214, Saihu, S. (2019). PENDIDIKAN KARAKTER BERBASIS KEARIFAN LOKAL (STUDI DI JEMBRANA BALI). Edukasi Islami: Jurnal Pendidikan Islam, 8(01), 69-90, Şahin, C. RELIGIA, Saihu, S., \& Mailana, A. (2019). Teori pendidikan behavioristik pembentukan karakter masyarakat muslim dalam tradisi Ngejot di Bali. Ta'dibuna: Jurnal Pendidikan Islam, 8(2), 163-176. Mubin, F. KEADILAN DALAM GENDER: KAJIAN KEPEMIMPINAN WANITA DALAM ISLAM1, Saihu, M. (2019). Merawat Pluralisme Merawat Indonesia (Potret Pendidikan Pluralisme Agama Di Jembrana-Bali). Deepublish.

7 Burhanuddin Salam, Pengantar Pedagogik, Jakarta: Rineka Cipta, 1997, hlm. 4

8 Umar Tirtarahardja \& La Sulo, Pengantar Pendidikan, Jakarta: Rineka Cipta, 2005, hlm. 37 
efektif dan efisien dan efisien serta sesuai dengan kebutuhan dan tujuan para peserta didik dan masyarakat.

f. Menurut Y. Dror (1975)

Perencanaan Pendidikan merupakan suatu proses mempersiapkan seperangkat keputusan untuk kegiatan-kegiatan di masa depan yang di arahkan untuk mencapai tujuan-tujuan dengan cara-cara optimal untuk pembangunan ekonomi dan social secara menyeluruh dari suatu Negara.

Perencanaan pendidikan adalah kegiatan yang berkaitan dengan usaha merumuskan program pendidikan yang di dalamnya memuat segala sesuatu yang akan dilaksanakan, penentuan tujuan pendidikan, kebijakan dalam pendidikan, arah yang akan ditempuh dalam kegiatan pendidikan, prosedur dan metode yang akan diikuti dalam usaha pencapaian tujuan pendidikan. ${ }^{9}$ Dalam proses perencanaan pendidikan merupakan keseluruhan proses perkiraan dan penentuan secara matang hal-hal yang akan dikerjakan dalam pendidikan untuk masa yang akan datang. ${ }^{10}$

Perencanaan pendidikan adalah suatu proses berpikir yang mendalam, menganalisis, merumuskan, dan menimbang serta memutuskan hal-hal yang dapat digunakan dalam mencapai tujuan yang telah ditetapkan atau dapat pula dikatakan bahwa perencanaan pendidikan adalah kegiatan yang akan dilakukan di masa yang akan datang untuk mencapai tujuan dalam bidang pendidikan. ${ }^{11}$ Perencanaan dan manajemen pendidikan diarahkan untuk dapat membantu:

1. memenuhi keperluan akan tenaga kerja,

2. perluasan kesempatan pendidikan,

3. peningkatan mutu pendidikan, serta

4. peningkatan efektivitas dan efisiensi penyelenggaraan pendidikan. ${ }^{12}$

Ada empat persoalan pokok yang dibicarakan dalam perencanaan pendidikan, yaitu:

a. Tujuan pendidikan

Sebagai suatu yang akan dicapai melalui kegiatan perencanaan pendidikan.

b. Status sistem pendidikan

Menunjuk kepada bagaimana suatu sistem pendidikan yang ada sekarang apakah sudah mencpai target-targetnya atau belum.

c. Alternatif pemecahan masalah

Menunjuk kepada kemungkinan-kemungkinan apakah yang dapat dipilih untuk mencapai tujuan yang telah ditetapkan. ${ }^{13}$

d. Strategi pencapaian tujuan

Menunjuk kepada cara terbaik mencapai tujuan itu. ${ }^{14}$

9 Hikmam,, Manajemen Pendidikan, Bandung: Pustaka Setia, 2009, hlm. 101

10 Ibid., hlm.102

11 Wina Sanjaya, Perencanaan dan Desain Sitem Pembelajaran, Jakarta: Prenadamedia Group, 2015, hlm. 25

12 Manap Somantri, Perencanaan Pendidikan, Jakarta: Taman Kencana, 2014, hlm. 14

13 Matin, Perencanaan Pendidikan Perspektif Proses dan teknik dalam Penyusunan Rencana Pendidikan, Jakarta: Raja Grafindo Persada, 2013, hlm. 1

14 Ibid., hlm. 2 


\section{B. Unsur Perencanaan Pendidikan}

Udin Syaefudin dan Abin Syamsuddin menguraikan beberapa unsur penting yang terkandung dalam perencanaan pendidikan, yaitu :

1. Penggunaan analisis yang bersifat rasional dan sistematis dalam perencanaan pendidikan, yang menyangkut metodologi dalam perencanaan.

2. Proses pembangunan dan pengembanngan pendidikan, artinya bahwa perencanaan pendidikan dilakukan dalam langka reformasi pendidikan, yaitu suatu proses dari status sekarang menuju status perkembangan pendidikan yang dicita-citakan. Perencanaan merupakan suatu moment kegiatan dalam proses yang continue.

3. Prinsip efektivitas dan efisiensi, artinya dalam perencanaan pendidikan itu, pemikiran secara ekonomis sangat menonjol, misalnya dalam hal penggalian sumber pembiayaan pendidikan, alokasi biaya, hubungan pendidikan denngan tenaga kerja, hubungan pengembangan pendidikan dengan pertumbuhan ekonomi. ${ }^{15}$

4. Kebutuhan dan tujuan peserta didik dan masyarakat (lokal, regional, nasional, dan internasioanal), artinya perencanaan pendidikan itu mencakup aspek internal dan eksternal dari keorganisasian sistem pendidikan itu sendiri.

5. Tujuan pembangunan nasional bangsa yang akan mengambil keputusan dalam rangka kebijaksanaan nasional dalam bidang pendidikn. Target yang hendak dicapai dengan melakkukan tujuan pendidikan nasional, dan berarti cara penyampaiannya pun, memengaruhi di dalamnya. Misalnya, waktu pelaksanaan, pertahapan, taktis, dan strategi dalam meletakkan jalur kebijakan ke mana akan dibawa pendidikan itu.

6. Masalah strategi adalah termasuk penanganan policy (kebijakan) secara operasional yang akan mewarnai proses pelaksanaan dari perencanaan pendidikan. Ketepatan peletakan strategi ini sangat penting. Hal-hal yang perlu mendapatkan perhatian dalam penanganan policy (kebijakan) adalah berkenaan dengan :

a. Sifat dan kebijakan nasional pendidikan.

b. Proses sosial yang dalam tingkat sedang berkembang

c. Cara pendekatan yang dipergunakan sebagai watak sistem perencanaannya.

Dari berbagai rumusan tentang perencanaan pendidikan dapat dimaklumi bahwa masalah yang menonjol adalah proses untuk menyiapkan konsep keputusaan yang akan dilaksanakan pada masa depan. Untuk jenis masyarakat, kepemimpinan politik, intelektual dan sosial sebagaimana, atau untuk jenis kemampuankemampuan tenaga kerja apa pendidikan itu darahkan? Semakin tajam dapat melihat jauh ke masa depan, semakin jelas arah tujuan seseorang. Rencana jangka panjang atau perspektif yang dapat menemukan dan menjelaskan arah dan garisgaris besar adalah suatu alat yang sangat berguna. ${ }^{16}$

\section{Prinsip Perencanaan Pendidikan}

15 Afifuddin, Perencanaan Pendidikan, Bandung: Pustaka Setia, 2011, hlm. 29

16 Ibid., hlm. 30 
Perencanaan pendidikan mengenal prinsip-prinsip yang dapat dijadikan pegangan, baik dalam proses penyusunan maupun dalam proses implementasinya. Prinsip-prinsip tersebut antara lain sebagai berikut: ${ }^{17}$

1. Prinsip interdisipliner, yaitu menyangkut berbagai bidang keilmuan atau beragam kehidupan. Hal ini penting karena hakikat layanan pendidikan kepada peserta didik harus menyangkut berbagai jenis pengetahuan, beragam ketrampilan dan nilai-norma kehidupan yang berlaku di masyarakat.

2. Prinsip fleksibel, yaitu bersifat lentur, dinamik dan responsif terhadap perkembangan atau perubahan kehidupan di masyarakat. Hal ini penting, karena hakikat layanan pendidikan kepada peserta didik adalah menyiapkan siswa untuk mampu menghadapi perkembangan ilmu pengetahuan dan teknologi (iptek) dan beragam tantangan kehidupan terkini.

3. Prinsip efektifitas-efisiensi, artinya dalam penyusunan perencanaan pendidikan didasarkan pada perhitungan sumber daya yang ada secara cermat dan matang, sehingga perencanaan itu 'berhasil guna' dan 'bernilai guna' dalam pencapaian tujuan pendidikan.

4. Prinsip progress of change, yaitu terus mendorong dan memberi peluang kepada semua warga sekolah untuk berkarya dan bergerak maju ke depan dengan beragam pembaharuan layanan pendidikan yang lebih berkualitas, sesuai dengan peranan masing-masing.

5. Prinsip objektif, rasional dan sistematis, artinya perencanaan pendidikan harus disusun berdasarkan data yang ada, berdasarkan analisa kebutuhan dan kemanfaatan layanan pendidikan secara rasional (memungkinkan untuk diwujudkan secara nyata), dan mempunyai sistematika dan tahapan pencapaian program secara jelas dan berkesinambungan.

6. Prinsip kooperatif-komprehensif, artinya perencanaan yang disusun mampu memotivasi dan membangun mentalitas semua warga sekolah dalam bekerja sebagai suatu tim (team work) yang baik. Disamping itu perencanaan yang disusun harus mencakup seluruh aspek esensial (mendasar) tentang layanan pendidikan akademik dan non-akademik setiap peserta didik.

7. Prinsip human resources development, artinya perencanaan pendidikan harus disusun sebaik mungkin dan mampu menjadi acuan dalam pengembangan sumber daya manusia secara maksimal dalam mensukseskan program pembangunan pendidikan. Layanan pendidikan pada peserta didik harus benarbenar mampu membangun individu yang unggul baik dari aspek intelektual (penguasaan science and technology), aspek emosional (kepribadian atau akhlak), dan aspek spiritual (keimanan dan ketakwaan), atau disebut IESQ yang unggul.

Setelah mengetahui prinsip perencanaan pendidikan yang tersebut di atas, maka proses atau tahapan penyusunan perencanaan pendidikan dapat dijalankan. Menurut Banghart and Trull dalam Sa'ud (2007) ada beberapa tahapan yang semestinya dilalui dalam penyusunan perencanaan pendidikan, antara lain:

17 Mubin, F. (2019). TAFSIR EMANSIPATORIS: PEMBUMIAN METODOLOGI TAFSIR PEMBEBASAN. Mumtaz: Jurnal Studi Al-Quran dan Keislaman,3(1), 131-151. Mubin, F. MODELMODEL PEMBELAJARAN BERBASIS MADRASAH DAN KEGIATAN LAIN YANG DIPERLUKAN DI DALAMNYA (FAKTOR PENDUKUNGNYA). 
1. Tahap need assessment, yaitu melakukan kajian terhadap beragam kebutuhan atau taksiran yang diperlukan dalam proses pembangunan atau pelayanan pembelajaran di setiap satuan pendidikan. Kajian awal ini harus cermat, karena fungsi kajian akan memberikan masukan tentang: (a) pencapaian program sebelumnya; (b) sumber daya apa yang tersedia, dan (c) apa yang akan dilakukan dan bagaimana tantangan ke depan yang akan dihadapi.

2. Tahap formulation of goals and objective, yaitu perumusan tujuan dan sasaran perencanaan yang hendak dicapai. Perumusan tujuan perencanaan pendidikan harus berdasarkan pada visi, misi dan hasil kajian awal tentang beragam kebutuhan atau taksiran (assessment) layanan pendidikan yang diperlukan.

3. Tahap policy and priority setting, yaitu merancang tentang rumusan prioritas kebijakan apa yang akan dilaksanakan dalam layanan pendidikan. Rumusan prioritas kebijakan ini harus dijabarkan kedalam strategi dasar layanan pendidikan yang jelas, agar memudahkan dalam pencapaian tujuan.

4. Tahap program and project formulation, yaitu rumusan program dan proyek pelaksanaan kegiatan operasional perencanaan pendidikan, menyangkut layanan pedidikan pada aspek akademik dan non akademik.

5. Tahap feasibility testing, yaitu dilakukan uji kelayakan tentang beragam sumber daya (sumber daya internal/ eksternal; atau sumber daya manusia/ material). Apabila perencanaan disusun berdasarkan sumber daya yang tersedia secara cermat dan akurat, akan menghasilkan tingkat kelayakan rencana pendidikan yang baik.

6. Tahap plan implementation, yaitu tahap pelaksanaan perencanaan pendidikan untuk mewujudkan tujuan pendidikan. Keberhasilan tahap ini sangat ditentukan oleh: (a) kualitas sumber daya manusianya (kepala sekolah, guru, komite sekolah, karyawan, dan siswa); (b) iklim atau pola kerjasama antar unsur dalam satuan pendidikan sebagai suatu tim kerja (team work) yang handal; dan (c) kontrol atau pengawasan dan pengendalian kegiatan selama proses pelaksanaan atau implementasi program layanan pendidikan.

7. Tahap evaluation and revision for future plan, yaitu kegiatan untuk menilai (mengevaluasi) tingkat keberhasilan pelaksanaan program atau perencanaan pendidikan, sebagai feedback (masukan atau umpan balik), selanjutnya dilakukan revisi program untuk rencana layanan pendidikan berikutnya yang lebih baik.

\section{Ruang Lingkup Perencanaan Pendidikan}

Ruang lingkup perencanaan pendidikan jangkauannya yang cukup luas dan dapat ditinjau dari berbagai aspek antara lain:

1. Ditinjau dari aspek spesialnya yaitu perencanaan pendidikan yang memiliki karakter yang terkait dengan ruang, tempat, atau batasan wilayah. Perencanaan ini terbagi menjadi: ${ }^{18}$

a. Perencanaan pendidikan nasional, yaitu mencakup seluruh proses usaha layanan pendidikan yang dilakukan oleh pemerintah pusat, yang bertujuan untuk mencapai tujuan pendidikan nasional, yang meliputi seluruh jenjang pendidikan dari tingkat dasar sampai perguruan tinggi, yang diatur dalam

18 Afifuddin, Op.cit., hlm. 32 
sistem pendidikan nasional melalui undang-undang sistem pendidikan nasional.

b. Perencanaan pendidikan ragional, yaitu perencanaan pendidikan yang dibuat dan diberlakukan dalam wilayah regional tertentu misalnya perencanaan pengembangan layanan pendidikan tingkat provinsi dan kebupaten/kota, yang menyangkut seluruh jenis layanan pendidikan di semua jenjang untuk daerah atau provinsi tertentu.

c. Perencanaan pendidikan kelembagaan, yaitu perencanaan pendidikan mencakup satu intuisi atau lembaga pendidikan tertentu, misalnya perencanaan pengembangan layanan pendidikan sekolah menengah atas.

2. Ditinjau dari aspek sifat dan karakteristik modelnya dapat dibagi menjadi:

a. Perencanaan pendidikan yang mencakup seluruh aspek yang terkait dengan proses pembangunan pendidikan yang esensial, dalam koridor perencanaan pembangunan nasional, dalam hal ini perencanaan pendidikan ada keterpaduan atau peterkaitan secara sistemik dengan perencanaan pembangunan bidang ekonomi, pilitik, hukum dan seb againya.

b. Perencanaan pendidikan komprehensif yaitu perencanaan pendidikan yang disusun secara sistematik, rasional, objektif, yang menyangkut keseuruhan konsep penting dalam layanan pendidikan, sehingga perencanaan itu memberikan suatu pemahaman yang lengkap atau sempurna tentang apa dan bagaimana memberikan layanan pendidikan yang berkualitas.

c. Perencanaan pendidikan strategik, yaitu perencanaan pendidikan yang mengandung pokok-pokok perencanaan untuk menjawab persoalan atau opini, atau isu mutakhir yang dihadapi oleh dunia pendidikan misalnya persoalan yang dihadapi dunia pendidikan sekarang adalah masalah rendahnya kualitas guru. ${ }^{19}$

\section{KESIMPULAN}

1. Definisi Perencanaan Pendidikan adalah suatu proses intelektual yang berkesinambungan dalam merencanakan, menganalisis, merumuskan, dan menimbang serta memutuskan sesuatu yang konsistensi (taat asas) internal yang berhubungan secara sistematis dengan keputusan-keputusan lain, baik dalam bidang-bidang itu sendiri maupun dalam bidang-bidang lain dalam pembangunan, dan tidak ada batas waktu untuk satu jenis kegiatan, serta tidak harus selalu satu kegiatan mendahului dan didahului oleh kegiatan lain. Selain itu, perencanaan pendidikan juga merupakan suatu proses berpikir yang mendalam, menganalisis, merumuskan, dan menimbang serta memutuskan hal-hal yang dapat digunakan dalam mencapai tujuan yang telah ditetapkan atau dapat pula dikatakan bahwa perencanaan pendidikan adalah kegiatan yang akan dilakukan di masa yang akan datang untuk mencapai tujuan dalam bidang pendidikan.

2. Berangkat dari hal tersebut di atas, dapat di tarik benang merah tentang karakteristik perencanaan pendidikan yakni meliputi : harus mengutamakan nilai manusiawi,dapat memberikan kesempatan untuk mengembangkan potensi peserta didik, harus memberikan kesempatan pendidikan yang sama kepada peserta didik, 
dibuat secara sistematis dan komperhensif, logis/rasional, harus berorintasi pada pembangunan, menggunakan SDM secermat mungkin, berorientasi pada masa depan, responsif terhadap kebutuhan yang berkembang di masyarakat, sarana untuk mengembangkan inovasi pendidikan hingga terjadi pembaharuan secara terus menerus.

3. Prinsip perencanaan pendidikan meliputi Prinsip interdisipliner, Prinsip fleksibel, Prinsip efektifitas-efisiensi, Prinsip progress of change, Prinsip objektif, rasional dan sistematis, Prinsip kooperatif-komprehensif,Prinsip human resources development.

4. Udin Syaefudin dan Abin Syamsuddin menguraikan beberapa unsur penting yang terkandung dalam perencanaan pendidikan, yaitu : penggunaan analisis yang bersifat rasional dan sistematis dalam perencanaan pendidikan, Proses pembangunan dan pengembanngan pendidikan, prinsip efektivitas dan efisiensi, kebutuhan dan tujuan peserta didik dan masyarakat, tujuan pembangunan nasional bangsa, dan masalah strategi.

5. Prinsip Perencanaan Pendidikan yaitu: interdisipliner, fleksibel, objektif rasional, tidak dimulai dari nol tetapi dari apa yang dimiliki, wahana untuk menghimpun kekuatan-kekuatan secara terkoordinasi disusun dengan data, mengendalikan kekuatan sendiri, komprehensif dan ilmiah.

6. Ruang lingkup perencanaan pendidikan jangkauannya yang cukup luas dan dapat ditinjau dari berbagai aspek antara lain:

a. Ditinjau dari aspek spesialnya yaitu perencanaan pendidikan yang memiliki karakter yang terkait dengan ruang, tempat, atau batasan wilayah. Perencanaan ini terbagi menjadi: ${ }^{20}$ Perencanaan pendidikan nasional, perencanaan pendidikan ragional, dan perencanaan pendidikan kelembagaan.

b. Ditinjau dari aspek sifat dan karakteristik modelnya dapat dibagi menjadi: Perencanaan pendidikan yang mencakup seluruh aspek yang terkait dengan proses pembangunan pendidikan yang esensial, perencanaan pendidikan komprehensif, dan perencanaan pendidikan strategik. 


\section{DAFTAR PUSTAKA}

Afifuddin, Perencanaan Pendidikan, Bandung: Pustaka Setia, 2011.

Aziz, A., \& Saihu, S. (2019). Interpretasi Humanistik Kebahasaan: Upaya Kontekstualisasi Kaidah Bahasa Arab. Arabiyatuna: Jurnal Bahasa Arab, 3(2), 299-214

Hidayat Achmad, Teknik Perencanaan Pendidikan Model Bar Chart Dan Network Planning (Pert Dan Cpm), Jurnal Ilmu Tarbiyah “At-Tajdid”, Vol. 4, No. 1, Januari 2015.

Hikmam,, Manajemen Pendidikan, Bandung: Pustaka Setia, 2009.

Matin, Perencanaan Pendidikan Perspektif Proses dan teknik dalam Penyusunan Rencana Pendidikan, Jakarta: Raja Grafindo Persada, 2013.

Mubin, F. (2019). TAFSIR EMANSIPATORIS: PEMBUMIAN METODOLOGI TAFSIR PEMBEBASAN. Mumtaz: Jurnal Studi Al-Quran dan Keislaman, 3(1), 131-151.

Mubin, F. KEADILAN DALAM GENDER: KAJIAN KEPEMIMPINAN WANITA DALAM ISLAM1,

Mubin, F. MODEL-MODEL PEMBELAJARAN BERBASIS MADRASAH DAN KEGIATAN LAIN YANG DIPERLUKAN DI DALAMNYA (FAKTOR PENDUKUNGNYA).

Pidarta Made, Perencanaan Pendidikan Partisipatoris Dengan Pendekatan Sistem, Jakarta: Rineka Cipta, 1990.

Ronaldo, R., Zulfikar, A., Saihu, Ismail, \& Wekke, I. S. (2020). International relations of the asia pacific in the age of trump. Journal of Environmental Treatment Techniques, 8(1), 244-246. 
Şahin, C. RELIGIA.

Saihu, Aziz, A., Mubin, F., \& Sarnoto, A. Z. (2020). Design of islamic education based on local wisdom (An analysis of social learning theories in forming character through ngejot tradition in bali). International Journal of Advanced Science and Technology, 29(6), 1278-1293.

Saihu, M. (2019). Urgensi 'Urf dalam Tradisi Male dan Relevansinya dalam Dakwah Islam di Jembrana-Bali. Jurnal Bimas Islam, 12(1), 173-201.

Saihu, M. (2019). Merawat Pluralisme Merawat Indonesia (Potret Pendidikan Pluralisme Agama Di Jembrana-Bali). Deepublish.

Saihu, M. M., \& Aziz, A. (2020). Implementasi Metode Pendidikan Pluralisme Dalam Mata Pelajaran Pendidikan Agama Islam. Belajea; Jurnal Pendidikan Islam, 5(1), 131-150.

Saihu, S. (2019). IMPLEMENTASI MANAJEMEN BALANCED SCORECARD DI PONDOK PESANTREN JAM'IYYAH ISLAMIYYAH TANGERANG SELATAN. Mumtaz: Jurnal Studi Al-Quran dan Keislaman, 3(1), 1-22.

Saihu, S. (2019). KOMUNIKASI PENDIDIK TERHADAP ANAK BERKEBUTUHAN KHUSUS DI SEKOLAH KHUSUS ASY-SYIFA LARANGAN. Andragogi: Jurnal Pendidikan Islam dan Manajemen Pendidikan Islam, 1(3), 418-440.

Saihu, S. (2019). KONSEP MANUSIA DAN IMPLEMENTASINYA DALAM PERUMUSAN TUJUAN PENDIDIKAN ISLAM MENURUT MURTADHA MUTHAHHARI. Andragogi: Jurnal Pendidikan Islam dan Manajemen Pendidikan Islam, 1(2), 197-217.

Saihu, S. (2019). PENDIDIKAN KARAKTER BERBASIS KEARIFAN LOKAL (STUDI DI JEMBRANA BALI). Edukasi Islami: Jurnal Pendidikan Islam, 8(01), 69-90.

Saihu, S. (2019). Pendidikan Pluralisme Agama: Kajian tentang Integrasi Budaya dan Agama dalam Menyelesaikan Konflik Sosial Kontemporer. Jurnal IndoIslamika, 9(1), 67-90,

Saihu, S. (2019). RINTISAN PERADABAN PROFETIK UMAT MANUSIA MELALUI PERISTIWA TURUNNYA ADAM AS KE-DUNIA. Mumtaz: Jurnal Studi AlQuran dan Keislaman, 3(2), 268-279,

Saihu, S. (2020). ETIKA MENUNTUT ILMU MENURUT KITAB TA'LIM MUTA'ALIM. Al Amin: Jurnal Kajian Ilmu dan Budaya Islam, 3(1), 99-112.

Saihu, S. (2020). KONSEP PEMBAHARUAN PENDIDIKAN ISLAM MENURUT FAZLURRAHMAN. Andragogi: Jurnal Pendidikan Islam dan Manajemen Pendidikan Islam, 2(1), 82-95.

Saihu, S. (2020). Pendidikan sosial yang terkandung dalam Surat At-Taubah Ayat 7172. Edukasi Islami: Jurnal Pendidikan Islam, 9(01), 127-148.

Saihu, S. (2020). The Effect of Using Talking Stick Learning Model on Student Learning Outcomes in Islamic Primary School of Jamiatul Khair, Ciledug Tangerang. Tarbawi: Jurnal Keilmuan Manajemen Pendidikan, 6(01), 61-68.

Saihu, S., \& Mailana, A. (2019). Teori pendidikan behavioristik pembentukan karakter masyarakat muslim dalam tradisi Ngejot di Bali. Ta'dibuna: Jurnal Pendidikan Islam, 8(2), 163-176.

Saihu, S., \& Marsiti, M. (2019). PENDIDIKAN KARAKTER DALAM UPAYA MENANGKAL RADIKALISME DI SMA NEGERI 3 KOTA DEPOK, JAWA BARAT. Andragogi: Jurnal Pendidikan Islam dan Manajemen Pendidikan Islam, 1(1), 23-54. 
Saihu, S., \& Rohman, B. (2019). PEMBENTUKAN KARAKTER MELALUI MODEL PENDIDIKAN TRANSFROMATIFE LEARNING PADA SANTRI DI PONDOK PESANTREN NURUL IKHLAS BALI. Edukasi Islami: Jurnal Pendidikan Islam, 8(02), 435-452.

Saihu, S., \& Taufik, T. (2019). PERLINDUNGAN HUKUM BAGI GURU. Al Amin: Jurnal Kajian Ilmu dan Budaya Islam, 2(2), 105-116.

Salam Burhanuddin, Pengantar Pedagogik, Jakarta: Rineka Cipta, 1997.

Sanjaya Wina, Perencanaan dan Desain Sitem Pembelajaran, Jakarta: Prenadamedia Group, 2015.

Saraswati, Kearifan Budaya Lokal Dalam Persfektif Teori Perencanaan, Jurnal PWK Unisba.

Siti Aisyah, Perencanaan Dalam Pendidikan (Jurnal Pendidikan Islam, Volume 7 No. 1 November 2018, Hal. 715-716)

Somantri Manap, Perencanaan Pendidikan, Jakarta: Taman Kencana, 2014.

Tirtarahardja Umar \& La Sulo, Pengantar Pendidikan, Jakarta: Rineka Cipta, 2005.

Utsman Kahar \& Nadhirin, Perencanaan Pendidikan, Kudus: STAIN Kudus, 2008. 